Resumen por el autor, Jacob Reighard.

Departamento de Zoología, Universidad de Michigan.

El almacenamiento y manejo de cuadros murales.

En vez de los listones de madera que se usan ordinariamente, el autor emplea listones de madera "basswood" teñidos con creosota. Las dimensiones de estos listones son $\frac{1}{4}$ de pulgada de espesor por $\frac{3}{4}$ de pulgada de anchura. Se clavan estos listones a los cuadros empleando clavos de alambre de $\frac{1}{2}$ pulgada de diámetro, y debajo de las cabezas de dichos clavos se perforan cuadrados de hierro galvanizado del num; 28. Los listones ocupan la superficie anterior de cada cuadro y los clavos se clavan en los lados libres. Cada listón superior lleva un gancho Hodge atornillado en el centro del listón. Cuando se hace girar al gancho de modo que venga a coincidir con el plano de la lámina, sirve para colgar esta última de una barra de hierro colocada en el cuarto en donde se guarden las láminas. De este modo éstas se conservan sin arrugas, y puesto que los listones ocupan muy poco espacio, pueden colgarse todas ellas de un modo semejante al de las hojas de un libro suspendido por el lomo. Las láminas se arreglan en orden de materias por medio de números, como si se tratase de un catálogo de materias, y cualquiera de ellas puede fácilmente sacarse $\mathrm{y}$ volverla a su sitio. Cuando se necesita usar una de las láminas se hace girar el gancho 90 grados, y entonces puede colgarse de un bastidor, alambre o cualquier otro soporte en la clase. Algunos de los mecanismos descritos han venido usándose hace largo tiempo; otros son nuevos. Sirven para coleccionar láminas de todos los tamaños en un espacio mínimo y para poderlas guardar en orden y emplearlas invirtiendo el menor tiempo posible. El presente trabajo indica donde pueden obtenerse los materiales empleados y su coste.

Translation by José F. Nonidez

Cornell University Medical College, N. Y. 
ALTHOR S ABRTRICT OF THIS PAPFR ISSUED

BY THE BIBLIOGRAPHIC EERVICE, MAY I0

\section{THE STORAGE AND HANDLING OF WALL CHARTS}

JACOB REIGHARD

Departmont of Zoology, University of Michigan

FOUR FIGURES

The maker usually supplies charts with wood rods tacked and glued to the ends. In use they are hung from hooks on the wall of the lecture room by means of two metal rings tacked to the upper rod. When stored they are rolled and tied about with tapes. In the Zoology Laboratory of the University of Michigan we have tried probably every known device for the storage of rolled charts. They may be piled on racks such as once were used at Harvard University. To make these, pieces of round iron, some 30 inches long or more, are bent for a couple of inches at the ends, flattened and drilled at the middle, and screwed horizontally to wooden uprights to as to project on both sides like large coat hooks and form two ladder-like sets of supports. On two such uprights, properly spaced, one may store many charts and classify them roughly. The uprights may be built on a base with casters beneath it and the whole contrivance wheeled from place to place. Labels may be written on discs of cardboard tacked to the ends of the chart rollers. As the charts accumulate and are piled several deep on each support, it is impossible to keep them in order and much time is wasted in locating and reading the small labels. In spite of the most ingenious labeling it is often necessary to unroll the charts to find those that are suitable, and this entails not only loss of time, but damage to the charts.

To find the charts more readily, we hare tried supporting them on pairs of large iron hooks screwed into vertical wood strips nailed to the walls of the lecture room. The charts then lie in one plane like the rungs of numerous ladders set against the wall. They may be classified and labels put beneath the groups. But 
as the collection grows it takes much wall space. It may become necessary to climb to reach the uppermost charts and they have still to be unrolled.

In place of supporting the rolled charts on metal rods, one may use deep wood frames divided into compartments like the boxes in a post office. These may be arranged to hold the charts in vertical or horizontal position, but we have found this plan as cumbersome and wasteful of time as the other.

Home-made charts accumulate in every laboratory and are apt to be of various sizes and of material that deteriorates if kept rolled and frequently unrolled. To avoid the labor of attaching them to rollers, one is tempted to let them lie flat, and we have piled them thus in large cases with numerous close-set shelves on which they may be roughly classified. It is not easy to label such charts so as to find readily what is wanted, and in pulling one from a pile for examination it is likely to be torn or damaged by rubbing. To return it to its proper place the whole pile must be taken out. Naturally one puts the chart back on top of its pile or on top of some other pile and the whole collection is thrown into confusion. In addition to this, if some charts are kept flat and others rolled, there are two places to look and time is wasted in the search.

In hanging the charts for use the two rings at the top must be put over hooks on the wall of the lecture room. To accommodate the unequal spacing of the suspension rings of different charts, the hooks must be movable. One may suspend picture hooks from a molding or wire and slip them along until the suspension rings of the chart will go over them and one must climb a ladder to do it. One may dispense with the ladder by using a wooden frame filled with wire netting and arranged to be raised and lowered by ropes and pulleys. The picture hooks may be stuck into the lowered netting at suitable intervals, the chart rings slipped over them, and the whole thing hoisted, or one may cover the hoistable frames with cotton cloth and pin or clip his charts to that.

After trying most of the plans outlined, we sought a means of keeping all charts in a minimum space in one collection with- 
out rolling them and so that they could be classified and examined and each removed and returned without disturbing the rest. We sought also the easiest way of hanging them for use. The result combines the unpublished devices of friends with some of my own. The universities in which I have seen some of these devices in use are indicated in parenthesis. I do not know that any other consistent scheme has been described in print.

We now store all our charts together by hanging them from a piece of $\frac{5}{8}$-inch iron pipe supported from the ceiling by a wire and stayed by wire to the side wall (Wisconsin). They are in a small room reserved for the purpose. The charts hang flat, one against another, like the leaves of a book. Because the wooden rods take too much room, we have removed them and have substituted thin strips of basswood (fig. 4, chart at right.) A thousand of these $\frac{1}{4} \times \frac{3}{4}$ inches by 40 inches, cut at a planing mill, now costs $\$ 18.00$. Probably any good soft wood would answer, but hardwood warps so that the strips do not stay flat. The strips are stained brown by dipping in creosote. They are tacked to the face of the chart along its ends by means of $\frac{1}{2}$ inch wire tacks or clout-nails set from 4 to 6 inches apart and clinched on the free face of the strips. To keep the heads of the nails from tearing through the charts we have put under each a piece of 28-gauge galvanized iron. This is $\frac{1}{2}$ inch square, perforated at the center, and has the corners turned with pliers to as to form small points that penetrate the chart and go a little way into the wood. We find it better not to use glue, and none of our charts attached to the strips by tacks in the manner described has yet come loose from its supports. A piece of sheet iron $2 \times 2$ feet now costs fifty cents, and from it about 1000 squares can be made in the laboratory.

For suspending the charts we use the hook devised by Prof. C. F. Hodge. It is screwed into the upper strip at such a point as to make the chart hang level. When the hook is turned into the plane of the chart it serves to suspend it from its support in the chart room as a suit of clothes is hung from a rail (fig. 1). When the chart is to be used, the hook is turned through 90 degrees and may then be slipped over a picture molding, wire, or other 


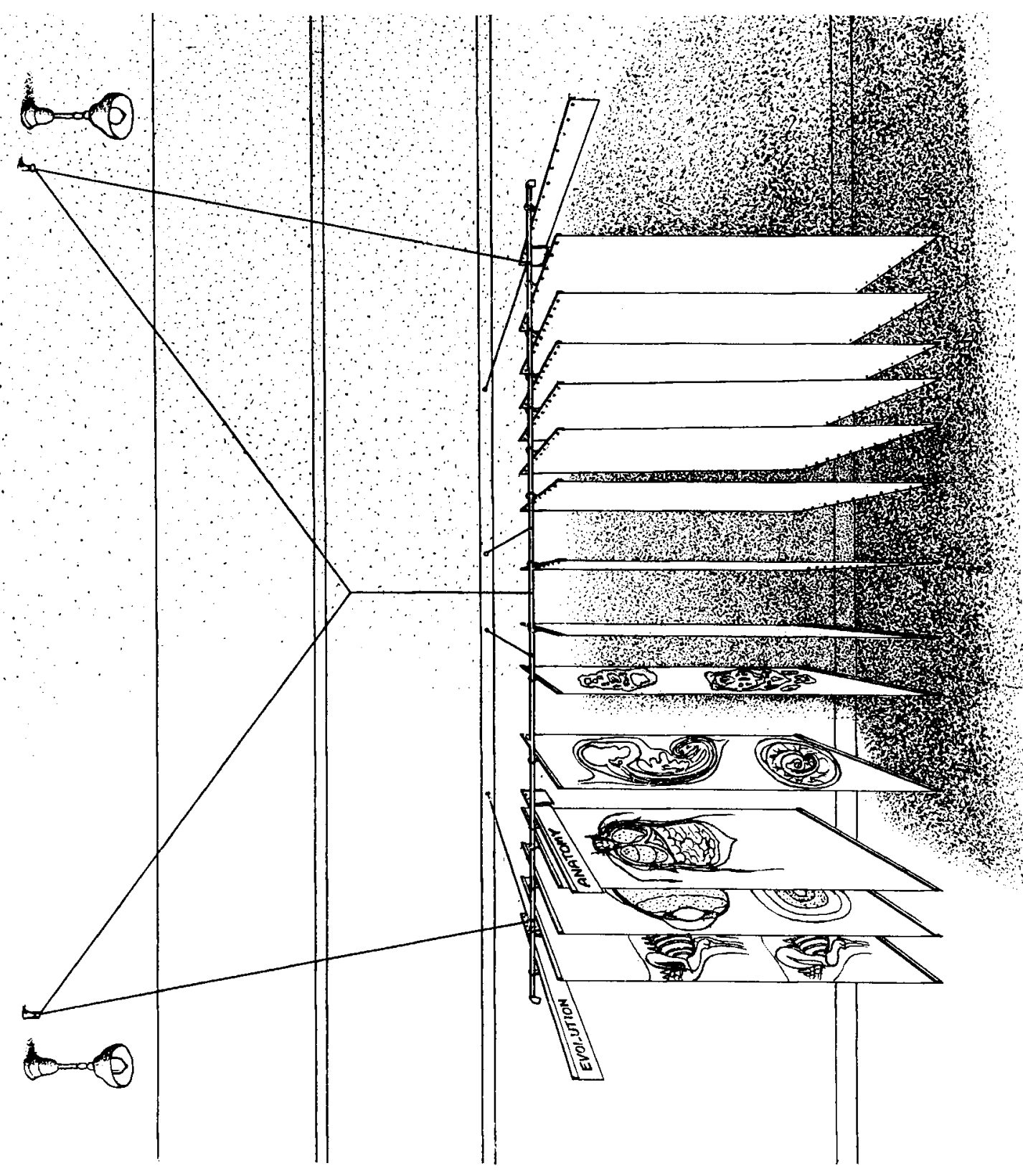

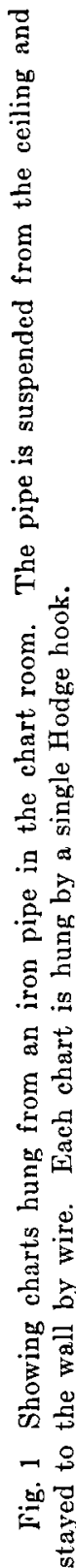


support in the lecture room. To hoist it into place and get it down again, we use a light wood pole $6 \frac{1}{2}$ feet long, also Professor Hodge's device. At one end the pole is provided with a ferrule through which is driven the sharpened end of a piece of $\frac{3}{8}$-inch round-iron. This is bent as shown in figure 3 and has its free end slotted to form a pair of claws like those on a tackhammer. The hump on the suspension hook fits between the

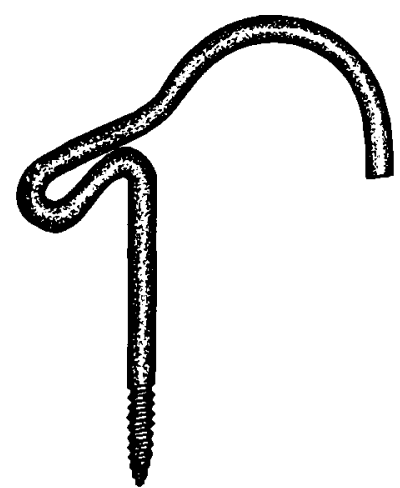

2

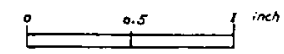

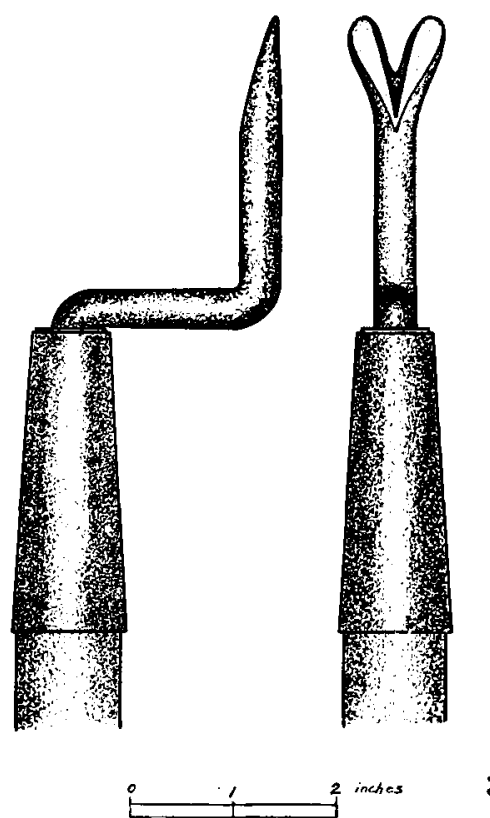

Fig. 2 'The Hodge hook. See text

Fig. 3 Pole for putting up and taking down charts. For description, see text

claws on the pole and permits the chart to be handled without waste of time. In each lecture room a short suspension rod is provided. To this the charts are transferred after use and from it an assistant collects them from time to time and returns them to the chart room. The Hodge hooks were obtained from the Wire Goods Co., Worcester, Massachusetts, and cost, before the war, $\$ 1.35$ per gross. The iron claw may be made by any blacksmith.

THE ANATOMICAL RECQRD, VOL. 19 , NO. 1 
For displaying charts in the lecture room we have used a modified form of a device made for displaying buggy robes, and used for charts at the University of Wisconsin. As used by us, this device consists of eighteen wood arms, each supported by an iron rod, and arranged to swing like the arm of a derrick (fig. 4). The arms are pivoted to steel sectors which turn on the central upright axis. By turning the sectors all the arms may be thrown either to right or left. Each arm supports two charts back to back. Any one of these may be brought into view by turning the arms as one turns the leaves of a book held vertically. The device may be attached to the wall, as ours is, or carried on a movable base resting on the floor. It may be obtained from John Best, Galva, Illinois, and cost (in 1915) \$19.00.

The whole arrangement has proved very satisfactory. The charts are designated by the numbers of the Concilium Bibliographicum gummed to the upper wood strip (fig. 4). They are arranged on the rail in systematic order, and any one may be located, removed, inspected, and returned to its place without difficulty. To subdivide them, index labels are hung at intervals (fig. 1). These are wood strips suspended from the rail by Hodge hooks. They project beyond the charts at one end and each bears at that end a square of chart cloth with an appropriate label and at the opposite end a thin bag of sand to balance it. Charts of any ordinary size may be accommodated. Very large maps may have to be kept rolled in a separate place, but they may be represented in the chart collection by appropriate dummies on which are written references to their location and to which may be attached photographs of them. Our collection consists now of 310 charts varying in size from $2 \times 2$ feet to $5 \frac{1}{2} \times 3$ feet and made of various materials. These occupy in storage a space 11 feet long, but the same space will probably accommodate nearly twice as many and still permit anyone to be examined in situ. If longer hooks were used the charts could be hung alternately high and low from parallel supports so that the wood strips would not be opposite. The same space would then accommodate many more. 

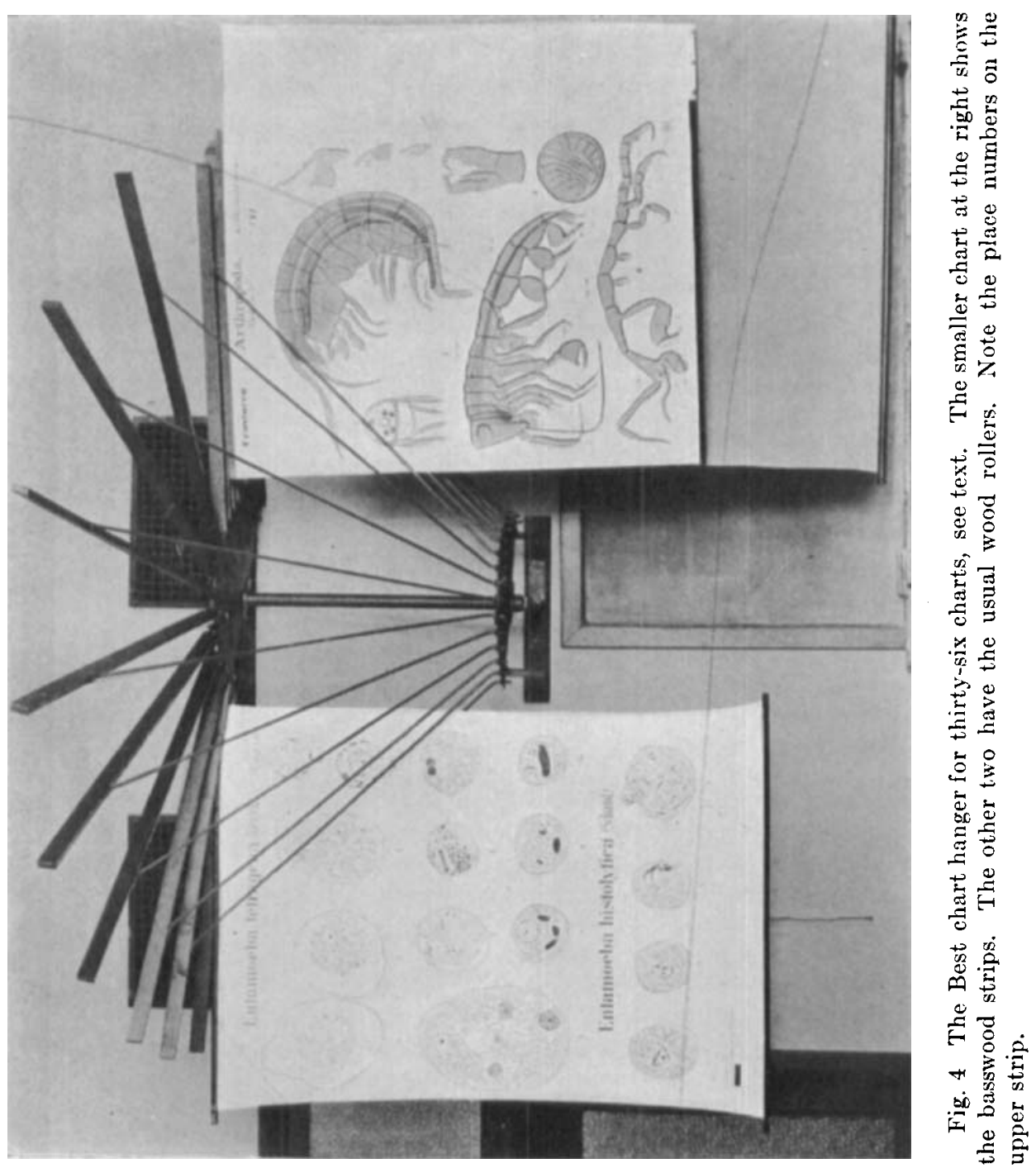
As our collection grows we shall make a card catalogue of the charts in which each chart will be represented by small photographs (Pennsylvania). By attaching concilium numbers to the duplicate photographs and arranging them according to the concilium system, cross references will be made to many of the charts. Thus the chart shown at the right in figure 4 would be represented in the catalogue by several photographic eards, each of which would bear an identical number to show the location of the charts in the collection. These cards would bear also distinctive concilium numbers by which they would be placed in the catalogue under crustacea, embryology, and under one or more anatomical designations. 